\title{
Effect of Duck Feet Gelatin on Physicochemical, Textural, and Sensory Properties of Low-fat Frankfurters
}

\author{
Eui-Joo Yeo, Hyun-Wook Kim, Ko-Eun Hwang, Dong-Heon Song, Yong-Jae Kim, Youn-Kyung Ham, \\ Fu-Yi He, Jae-Hyun Park, and Cheon-Jei Kim* \\ Department of Food Science and Biotechnology of Animal Resources, Konkuk University, Seoul 143-701, Korea
}

\begin{abstract}
Duck feet gelatin (DFG) gel was added as a fat replacer to low-fat frankfurters and the effect of DFG on physicochemical, textural, and sensory characteristics of low-fat frankfurters was evaluated. DFG gel was prepared with a $20 \%$ duck feet gelatin concentration (w/w). Adding DFG decreased lightness and increased yellowness of the low-fat frankfurters $(p<0.05)$. However, DFG did not affect redness of low-fat frankfurters $(p>0.05)$. The statistical results indicated that adding DFG improved cooking yield of low-fat frankfurters $(p<0.05)$. In addition, replacing pork back fat with DFG resulted in increased moisture content, protein content, and ash content of low-fat frankfurters, and the low-fat frankfurter formulated with $5 \%$ pork back fat and 15\% DFG gel had the highest moisture content and lowest fat content $(p<0.05)$. Adding of DFG increased all textural parameters including hardness, springiness, cohesiveness, chewiness, and gumminess of low-fat frankfurters $(p<0.05)$. In terms of sensory properties, the low-fat frankfurter formulated with $5 \%$ pork back fat and $15 \%$ DFG gel showed similar satisfaction scores for the flavor, tenderness, juiciness, and overall acceptance when compared to the regular frankfurters ( $20 \%$ back fat). Therefore, our results suggest that DFG could be an effective novel source, as a fat replacer, for manufacturing of low-fat frankfurters.
\end{abstract}

Keywords: duck feet gelatin, frankfurters, low-fat, quality characteristics

\section{Introduction}

Collagen is a major constituent of skin, tendons, and connective tissue, and it accounts for approximately onethird of the total proteins in the human body (Lin and Liu, 2006). Gelatin can be extracted with irreversible hydrolysis of collagen and this derived protein occupies a unique position in the theoretical and practical world of chemistry (Choi and Regenstein, 2000). Gelatin is widely applied in the pharmaceutical, cosmetic, photographic, and food industries due to its unique functional properties (Gómez-Guillén et al., 2011). In particular, gelatin has several technological properties, such as gel formation, texturizing, and water holding capacity, and is a useful additive for improving physicochemical and sensory characteristics of several types of meat products (GómezGuillén et al., 2011).

Gelatin is usually extracted from collagenous materials

\footnotetext{
*Corresponding author: Cheon Jei Kim, Department of Food Science and Biotechnology of Animal Resources, Konkuk University, Seoul 143-701, Korea. Tel: +82-2-450-3684, Fax: +82-2-444-6695, E-mail: kimcj@konkuk.ac.kr
}

such as pig skin or cow hide by acidic or alkali treatments. As sources of gelatin, pig skin, bovine hide, bone of pork and cattle are account for 46\%, 29.4\%, and $23.1 \%$, respectively (Gómez-Guillén et al., 2011). Recently, alternative sources of gelatin are needed for many years due to the emergence of bovine spongiform encephalopathy and foot-and-mouth disease (Kim et al., 2010). For these reasons, many researchers have been trying to develop and another source has been considered for producing gelatin especially fish by-products (Gudmundsson and Hafsteinsson, 1997; Nagai and Suzuki, 2000).

In case of poultry, as the consumption of poultry meat has increased, production of by-products like feathers, bones, and feet has also increased (Ockerman and Hansen, 2000). Poultry by-products, especially bird feet, contain large amounts of collagen (Lin and Liu, 2006). For chicken skin, major components of collagen are type I collagen (75\%) and type III collagen (15\%) (Cliche et al., 2003). Huda et al. (2013) investigated the effect of duck feet collagen (DFC) on physicochemical properties of surimi and found that DFC improved folding test score, expressible moisture, gel strength, and cooking loss. In addition, the functional properties of DFC were similar to 
cow and fish collagen. However, little information is available about the characteristics of duck feet gelatin and its application to meat products.

Health organizations are encouraging reduced fat intake, particularly cholesterol and saturated fatty acids, to prevent cardiovascular heart disease, obesity, and diabetes (Choi et al., 2012). However, Keeton (1994) revealed that fat contributed to the texture, flavor, and juiciness of a comminuted meat product. Additionally, fat is vital to the structural and rheological properties of meat products to stabilize and form the meat emulsion (Crehan et al., 2000). Due to the functions of fat in restructured meat products, such as emulsion type sausage, reducing the amount of added fat causes undesirable sensory characteristics in low-fat meat products (Keeton, 1994). To minimize these problem with low-fat meat product, several technological methods have been attempted by many researchers, such as massaging (Claus et al., 1990) and adding of functional ingredients such as dietary fiber (Choi et al., 2012), vegetable oil (Choi et al., 2009), or non-meat protein (Hsu and Sun, 2006). In a previous study, Prabhu et al. (2004) indicated that collagen protein could stabilize shrinkage and increase juiciness of meat product and that these function of collagen might be useful to reduce the rubberiness of low-fat frankfurters.

Therefore, the objective of this study was to investigate the effect of DFG gel, as a fat replacer, on the physicochemical, textural, and sensory properties of low-fat frankfurters.

\section{Materials and Methods}

\section{Preparation of duck feet gelatin}

Duck feet gelatin (DFG) was extracted with the method described by Park (2013). Duck feet skinless were obtained from a local market. Visible fat, dirt, and blood were removed with using tap water for several times and vacuum-packaged (FJ-500XL, Fujee Tech, Korea) with polyethylene bags. Vacuum-packaged duck feet were stored at $-20^{\circ} \mathrm{C}$ until use. For thawing process, flowing tap water was used and thawed duck feet were soaked in 0.1 $\mathrm{N} \mathrm{HCl}$ in 5 times $(\mathrm{v} / \mathrm{w})$ for $24 \mathrm{~h}$. After soaking, flowing tap water is used for neutralizing the swelled duck feet for

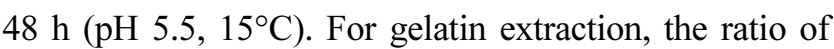
duck feet and water was $1: 1$ and heated at $75^{\circ} \mathrm{C}$ in a water bath (VS-1901W, Vision Scientific Co., Ltd., Korea) for 2 h. The gelatin extract from duck feet was filtered with sanitary cotton bag to remove residues and cooled at $4^{\circ} \mathrm{C}$. The gelatin gel was cut into $1 \times 1 \times 1 \mathrm{~cm}^{3}$ pieces and frozen at $-70 \pm 1{ }^{\circ} \mathrm{C}$. Freeze-drying of the gelatin gel was conducted under $80 \times 10^{-3}$ torr pressure at $-130^{\circ} \mathrm{C}$ using a freeze-dryer (PVTFD20R, Ilshinlab, Korea). The dry matter was referred to as 'DFG powder' and vacuum-packaged until use.

\section{Manufacturing process of low-fat frankfurters}

DFG powder which contains the protein content of $88.5 \%$ was dissolved at $60^{\circ} \mathrm{C}$ with water to prepare $20 \%$ gelatin solution $(\mathrm{w} / \mathrm{w})$ and cooled down at $4^{\circ} \mathrm{C}$. After

Table 1. Formulations of low-fat frankfurters made with duck feet gelatin (DFG) gel

\begin{tabular}{|c|c|c|c|c|c|}
\hline \multirow{2}{*}{ Ingredients $(\%, w / w)$} & \multirow{2}{*}{ Control } & \multirow{2}{*}{ Control-L } & \multicolumn{3}{|c|}{ Treatments ${ }^{I)}$} \\
\hline & & & T1 & $\mathrm{T} 2$ & $\mathrm{~T} 3$ \\
\hline Pork & 60 & 60 & 60 & 60 & 60 \\
\hline Ice $(\text { total })^{2)}$ & $20(20)$ & $30(30)$ & $20(28)$ & $20(30)$ & $20(32)$ \\
\hline Back fat & 20 & 10 & 10 & 7.5 & 5 \\
\hline DFG gel ${ }^{3)}$ & 0 & 0 & 10 & 12.5 & 15 \\
\hline Total & 100 & 100 & 100 & 100 & 100 \\
\hline $\mathrm{NPS}^{4)}$ & 1.2 & 1.2 & 1.2 & 1.2 & 1.2 \\
\hline Ascorbic acid & 0.02 & 0.02 & 0.02 & 0.02 & 0.02 \\
\hline $\mathrm{STPP}^{5)}$ & 0.3 & 0.3 & 0.3 & 0.3 & 0.3 \\
\hline Sugar & 0.5 & 0.5 & 0.5 & 0.5 & 0.5 \\
\hline $\mathrm{ISP}^{6}$ & 1 & 1 & 1 & 1 & 1 \\
\hline Bockwurst & 0.4 & 0.4 & 0.4 & 0.4 & 0.4 \\
\hline Wheat fiber & 1 & 1 & 1 & 1 & 1 \\
\hline
\end{tabular}

${ }^{1)}$ Treatments: Control, $20 \%$ back fat; Control-L, replacement of $10 \%$ back fat with only water; T1, replacement of $10 \%$ back fat with DFG gel; T2, replacement of $12.5 \%$ back fat with DFG gel; T3, replacement of $15 \%$ back fat with DFG gel.

${ }^{2)}$ Figure in parenthesis means total amount of water.

${ }^{3)}$ DFG gel, duck feet gelatin gel $(20 \%$, w/w).

${ }^{4)} \mathrm{NPS}$, nitrite pickled salt (99.4:0.6).

${ }^{5)} \mathrm{STPP}$, sodium tri-polyphosphate.

${ }^{6}$ ISP, isolated soy protein. 
cooling, the DFG gel was cut with knife in cube size $\left(1 \times 1 \times 1 \mathrm{~cm}^{3}\right)$. Fresh pork ham (Musculus biceps femoris, M. semitendinosus, M. semimembranosus, M. gracilis, and M. adductor) and pork back fat were ground through an 8-mm plate. The ground pork and DFG gel were homogenized and ground for $1 \mathrm{~min}$ in a silent cutter (Cutter Nr-963009, Germany). Then other additives were added to the meat emulsion. The formulation of low-fat frankfurters prepared with DFG gel is shown in Table 1. Control was prepared with $20 \%$ back fat, and low-fat control (control-L) was prepared with replacement of $10 \%$ back fact with only water. The low-fat frankfurters were formulated with replacement of $10 \%$ (T1), $12.5 \%$ (T2), and $15 \%$ (T3) back fat with DFG gel, respectively. A temperature probe (Kane-May, KM330, Germany) was used to monitor the temperature of the emulsion, which was maintained below $10^{\circ} \mathrm{C}$ during batter preparation. After emulsification, meat batter was stuffed into collagen casings (approximate diameter of $25 \mathrm{~mm}$ ) using a stuffer (Stuffer IS-8, Italy) and the sample were heated at $75^{\circ} \mathrm{C}$ for $40 \mathrm{~min}$ in a smoker (MAXI 3501, Kerres, Backnang, Germany). The cooked low-fat frankfurter were cooled at $10^{\circ} \mathrm{C}$ for $5 \mathrm{~min}$ and then and stored in a $4^{\circ} \mathrm{C}$ refrigerator during analysis on the day.

\section{Proximate composition}

Proximate composition of the low-fat frankfurters was measured using AOAC (2000). Moisture content (950.46 B) was determined by weight loss after $12 \mathrm{~h}$ of drying at $105^{\circ} \mathrm{C}$ in a drying oven (SW-90D, Sang Woo Scienctific Co., Korea). Fat content (960.39) by Soxhlet extraction (Soxtec ${ }^{\circledR}$ Avanti 2050 Auto System, Foss Tecator AB, Sweden). Protein content (981.10) was determined by Kjeldahl method with an automatic Kjeldahl nitrogen analyzer (Kjeltec ${ }^{\circledR} 2300$ Analyzer Unit, Foss Tecator AB, Sweden). Ash was determined according to the AOAC method 920.153 (muffle furnace).

\section{pH measurements}

The $\mathrm{pH}$ of $5 \mathrm{~g}$ samples blended with $20 \mathrm{~mL}$ distilled water for $60 \mathrm{~s}$ in a homogenizer at 8,000 rpm (Ultra-Turrax T25, Janke and Kunkel, Germany) was determined with a $\mathrm{pH}$ meter (Model 340, Mettler-Toledo GmbH, Switzerland).

\section{Instrumental color evaluation}

Color measurements were obtained with a colorimeter (Chroma meter CR-210, Minolta, Japan; illuminate C, calibrated with a white standard plate CIE L* $=97.83$, a* $\left.=-0.43, \mathrm{~b}^{*}=+1.98\right)$ using an $8 \mathrm{~mm}$ diameter measuring area and a $50-\mathrm{mm}$ diameter illumination area. Cross section of each frankfurter were measured in five replicates and lightness (CIE $\mathrm{L}^{*}$ value), redness (CIE a* value), and yellowness (CIE $\mathrm{b}^{*}$ value) values was recorded.

\section{Cooking yield}

Cooking yield was determined by calculating the weight difference between raw and cooked frankfurter, as follows:

\section{Cooking yield $(\%)=$}

[(weight of frankfurters after cooking (g) / weight of frankfurters before cooking $(\mathrm{g})] \times 100$

\section{Texture profile analysis (TPA)}

Texture profile analysis (TPA) of frankfurters was performed in triplicate on each sample at room temperature with a texture analyzer (TA-XT2i, Stable Micro Systems Ltd., England). Frankfurters were cut into sections with a height of $25 \mathrm{~mm}$ approximately. Samples were taken from the central portion and the conditions of texture analysis were as follows; pre-test speed $2.0 \mathrm{~mm} / \mathrm{s}$, post-test speed $5.0 \mathrm{~mm} / \mathrm{s}$, maximum load $2 \mathrm{~kg}$, test speed $2.0 \mathrm{~mm} / \mathrm{s}$, distance $12.0 \mathrm{~mm}$. The texture profile analysis parameters, namely hardness (peak force on first compression, $\mathrm{kg}$ ), springiness (ratio of the sample recovered after the first compression), cohesiveness (ratio of active work done under the second force-displacement curve to that done under the first compression curve), gumminess (hardness $\times$ cohesiveness), and chewiness (springiness $\times$ gumminess) were computed (Bourne, 1978).

\section{Sensory evaluation}

Sensory properties of low-fat frankfurters was evaluated for appearance, color, flavor, juiciness, tenderness, off-flavor and overall acceptability. After cooking, the low-fat frankfurters were cooled to $4^{\circ} \mathrm{C}$, cut into slices ( $25 \mathrm{~mm}$ diameter $\times 5 \mathrm{~mm}$ thick), and served to panelists in random order. Sensory evaluations were performed by the panelists that were under fluorescent lighting. Panelists were instructed to cleanse their palates between samples using water. The color $(1=$ extremely undesirable, $10=$ extremely desirable), flavor $(1=$ extremely undesirable, $10=$ extremely desirable), juiciness $(1=$ extremely dry, $10=$ extremely juicy $)$, tenderness $(1=$ extremely tough, $10=$ extremely tender $)$, off-flavor $(1=$ strong offflavor, $10=$ weak off-flavor $)$, and overall acceptance $(1=$ extremely undesirable, $10=$ extremely desirable) of the 
sausages were evaluated using a 10-point descriptive scale. The panel consisted of 11 members from the department of food sciences and biotechnology of animal resources at Konkuk University in Korea.

\section{Statistical analysis}

An analysis of variance was performed on all the variables using the General Linear Model (GLM) with added fat content and DFC levels as main effects using SAS statistical package (SAS Institute, Inc., 2010). Duncan's multiple range tests $(p<0.05)$ was used to determine differences between treatment means.

\section{Results and Discussion}

\section{pH value and color parameters}

The effect of replacing back fat with DFG gel on $\mathrm{pH}$ value and color parameter of low-fat frankfurters is shown in Table 2. The range of $\mathrm{pH}$ value in the low-fat frankfurters was 6.14 to 6.19 . The $\mathrm{pH}$ of control-L was slightly higher than that of the others $(p<0.05)$, but no significant difference was observed between other treatments $(p>$ 0.05 ). These results are similar to others studies that were conducted on the influences of fat and moisture levels in bologna sausage (Carballo et al., 1995; Claus and Hunt, 1991).

CIE L* (lightness) values of cooked frankfurters were 65.87-70.61, and the lightness of frankfurters were decreased significantly when addition of DFG gel increased $(p<0.05)$. These findings were consistent with those from other studies (Carballo et al., 1995; Claus and Hunt, 1991) which reported that reducing fat content in sausage decreases lightness. According to Pietrasik (1999), the whitish color of fat shows increased lightness as the proportion of fat is increased and also the light scattering properties of fat are associated with the darker appearance of low-fat meat products. The CIE a* (redness) value was not significantly affected by adding DFG gel $(p>0.05)$, but the CIE $b^{*}$ (yellowness) value increased significantly $(p<0.05)$. The yellowness of low-fat frankfurters might be affected by color characteristics of DFG. Prabhu et al. (2004) reported that adding collagen has no influence on lightness, redness or yellowness, but there was a tendency to decrease lightness and increase yellowness as the level of pork collagen increased.

\section{Cooking yield}

The effect of DFG gel on cooking yield of low-fat frankfurters is shown in Fig. 1. The control had the highest cooking yield among all treatments, whereas the cooking yield of control-L was significantly the lowest ( $p<$ 0.05 ). Cierach et al. (2009) reported that reducing fat causes a significant decrease in cooking yield, and a similar result was reported by Candogan and Kolsarici (2003). Although the control-L and T1 treatments were prepared with the equal back fat content, cooking yield of the T1 treatment was significantly higher than that of control-L $(p<0.05)$. The control-L and T2 treatments were formulated with same amount of water, however, the T2 treatment had a significantly higher cooking yield than that of control-L $(p<0.05)$, suggesting an effect of water-holding capacity of DFG. There was no significant difference among the low-fat frankfurters formulated with different levels of DFG gel $(p>0.05)$. However, the significant differences were observed between control and low-fat frankfurters when back fat was replaced with DFG gel at ratios of $12.5 \%$ and $15 \%(p<0.05)$. These results are similar to Huda et al. (2013) who showed that adding duck feet collagen causes less cooking loss than a control and they also found no significant differences between duck feet collagen and collagen derived from other sources such as fish or cow. In addition, Osburn et al. (1999) indicated that the connective tissue protein gel can be a potential water binder for low-fat meat products.

Table 2. Effect of replacing back fat with duck feet gelatin (DFG) gel on pH value and color parameters of low-fat frankfurters

\begin{tabular}{cccccc}
\hline \hline \multirow{2}{*}{ Traits } & \multirow{2}{*}{ Control } & \multirow{2}{*}{ Control-L } & \multicolumn{2}{c}{ Treatments } \\
\cline { 3 - 6 } & & & T1 & T2 & T3 \\
\hline $\mathrm{pH}$ & $6.15 \pm 0.01^{\mathrm{b}}$ & $6.19 \pm 0.02^{\mathrm{a}}$ & $6.14 \pm 0.01^{\mathrm{b}}$ & $6.14 \pm 0.01^{\mathrm{b}}$ & $6.15 \pm 0.02^{\mathrm{b}}$ \\
\hline \multicolumn{2}{c}{ Color parameters } & & & & \\
$\mathrm{CIE} \mathrm{L}^{*}$ & $69.63 \pm 0.33^{\mathrm{a}}$ & $70.61 \pm 1.14^{\mathrm{a}}$ & $67.71 \pm 1.53^{\mathrm{b}}$ & $66.36 \pm 1.32^{\mathrm{c}}$ & $65.87 \pm 1.13^{\mathrm{c}}$ \\
$\mathrm{CIE} \mathrm{a}^{*}$ & $9.36 \pm 0.43$ & $9.00 \pm 0.40$ & $9.05 \pm 0.91$ & $8.96 \pm 0.87$ & $8.97 \pm 0.45$ \\
$\mathrm{CIE} \mathrm{b}^{*}$ & $10.75 \pm 0.44^{\mathrm{b}}$ & $11.18 \pm 0.71^{\mathrm{b}}$ & $11.21 \pm 0.45^{\mathrm{b}}$ & $11.99 \pm 0.67^{\mathrm{a}}$ & $12.00 \pm 0.85^{\mathrm{a}}$ \\
\hline
\end{tabular}

All values are mean $\pm \mathrm{SD}$.

${ }^{1)}$ Treatments: Control, $20 \%$ back fat; Control-L, replacement of $10 \%$ back fat with only water; T1, replacement of $10 \%$ back fat with DFG gel; T2, replacement of $12.5 \%$ back fat with DFG gel; T3, replacement of $15 \%$ back fat with DFG gel.

${ }^{\mathrm{a}-\mathrm{c}}$ Means in a row with different superscript letters are significantly different $(p<0.05)$. 


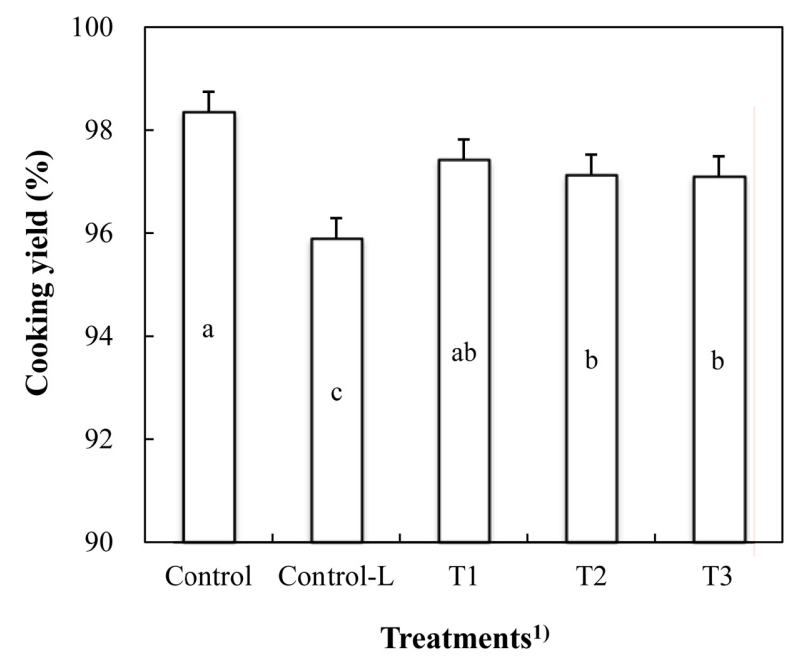

Fig. 1. Effect of replacing back fat with duck feet gelatin (DFG) gel on cooking yield of low-fat frankfurters. ${ }^{1)}$ Treatments: Control, $20 \%$ back fat; Control-L, replacement of $10 \%$ back fat with only water; $\mathrm{T} 1$, replacement of $10 \%$ back fat with DFG gel; T2, replacement of $12.5 \%$ back fat with DFG gel; T3, replacement of $15 \%$ back fat with DFG gel. a-c: Means with different superscript letters are significantly different $(p<0.05)$.

\section{Proximate composition}

The proximate composition of low-fat frankfurters prepared with DFG gel is presented in Table 3. The moisture content of low-fat frankfurters was higher than that of the control $(p<0.05)$. As the addition of DFG increased, moisture content of low-fat sausages also increased $(p<0.05)$. This result might be affected by moisture content within DFG gel. The cooking yield of low-fat frankfurters with DFG gel was not significant different among treatments (Fig. 1), but moisture content increased significantly as DFG gel level increased. Osburn and Mandigo (1998) noted that chicken skin connective tissue can act as waterbinder. Prabhu et al. (2004) indicated water-retaining activity of collagen. As showed earlier, yield decreased in cases of adding more water instead of pork back fat. This result caused a slight increase in protein content of the control-L treatment with concentrated effect $(p<0.05)$. The T1 treatment was higher in protein content than that of the control-L with an equal replacement ratio $(p<0.05)$. Adding DFG gel led to increased protein content in lowfat sausage due to large amount of protein within DFG gel $(p<0.05)$. Pereira et al. (2011) conducted study that the effects of adding of mechanically deboned poultry meat (MDPM) and collagen fiber on quality characteristics of frankfurter sausages and suggested that adding collagen fiber increases protein content of sausages. As expected, increasing the replacement ratio of pork back fat decreased fat content of the sausage $(p<0.05)$. Ash content was slightly lower in the control-L treatment than that in the other treatments $(p<0.05)$. This result could be due to the dilution effect as pork back fat was replaced with water in the case of control-L (Meullenet et al., 1994).

\section{Texture profile analysis (TPA)}

The effect of DFG gel on textural properties of low-fat frankfurters was assessed and the data are shown in Table 4. Hardness of control-L was the lowest among treatments $(p<0.05)$ and it was significantly lower than that of control $(p<0.05)$. Similarly, Hsu and Sun (2006) reported that reduction in added fat amount resulted in a negative effect on texture and overall acceptability. Low-fat frankfurters with DFG gel had higher hardness than that of the control-L and control $(p<0.05)$. As ratio of replacing pork back fat with DFG gel increased, the samples showed higher hardness $(p<0.05)$. Pereira et al. (2011) conducted a TPA test of sausage to reveal the effect of adding MDPM and collagen fiber, and observed that increasing the collagen fiber level led increased hardness of frankfurters. According to Prabhu et al. (2004), an increase in added amount of pork collagen (0-3.5\%) to frankfurters slightly increased the hardness which means more firmer texture.

The cohesiveness of low-fat sausage substituting back fat with water was the lowest among treatments $(p<0.05)$.

Table 3. Proximate composition of low-fat frankfurters prepared with duck feet gelatin (DFG) gel

\begin{tabular}{cccccc}
\hline \hline \multirow{2}{*}{ Traits (g/100 g) } & \multirow{2}{*}{ Control } & Control-L & \multicolumn{3}{c}{ Treatments } \\
\cline { 4 - 6 } & & & T1 & T2 & T3 \\
\hline Moisture & $63.09 \pm 0.68^{\mathrm{d}}$ & $71.42 \pm 0.31^{\mathrm{b}}$ & $69.82 \pm 0.66^{\mathrm{c}}$ & $71.35 \pm 0.71^{\mathrm{b}}$ & $72.88 \pm 0.68^{\mathrm{a}}$ \\
Protein & $13.60 \pm 0.47^{\mathrm{c}}$ & $14.91 \pm 0.47^{\mathrm{b}}$ & $17.06 \pm 0.64^{\mathrm{a}}$ & $17.20 \pm 0.55^{\mathrm{a}}$ & $17.96 \pm 0.88^{\mathrm{a}}$ \\
Fat & $19.24 \pm 0.92^{\mathrm{a}}$ & $11.28 \pm 0.89^{\mathrm{b}}$ & $10.49 \pm 0.74^{\mathrm{b}}$ & $8.46 \pm 0.79^{\mathrm{c}}$ & $6.34 \pm 0.94^{\mathrm{d}}$ \\
Ash & $1.83 \pm 0.08^{\mathrm{ab}}$ & $1.76 \pm 0.05^{\mathrm{b}}$ & $1.80 \pm 0.04^{\mathrm{ab}}$ & $1.81 \pm 0.02^{\mathrm{ab}}$ & $1.86 \pm 0.07^{\mathrm{a}}$ \\
\hline
\end{tabular}

All values are mean $\pm \mathrm{SD}$.

${ }^{1)}$ Treatments: Control, $20 \%$ back fat; Control-L, replacement of $10 \%$ back fat with only water; T1, replacement of $10 \%$ back fat with DFG gel; T2, replacement of $12.5 \%$ back fat with DFG gel; T3, replacement of $15 \%$ back fat with DFG gel.

${ }^{\mathrm{a}-\mathrm{d}}$ Means in a row with different superscript letters are significantly different $(p<0.05)$. 
Table 4. Texture profile analysis (TPA) of low-fat frankfurters formulated with duck feet gelatin (DFG) gel

\begin{tabular}{cccccc}
\hline \hline Traits & \multirow{2}{*}{ Control } & \multirow{2}{*}{ Control-L } & \multicolumn{2}{c}{ Treatments $^{\mathrm{I}}$} \\
\cline { 4 - 6 } & & & $\mathrm{T}$ & $\mathrm{T} 2$ & $\mathrm{~T}$ \\
\hline Hardness (kg) & $5.48 \pm 0.43^{\mathrm{c}}$ & $4.08 \pm 0.25^{\mathrm{d}}$ & $7.43 \pm 0.35^{\mathrm{b}}$ & $7.57 \pm 0.59^{\mathrm{b}}$ & $8.67 \pm 0.68^{\mathrm{a}}$ \\
Cohesiveness & $0.42 \pm 0.02^{\mathrm{b}}$ & $0.32 \pm 0.05^{\mathrm{c}}$ & $0.48 \pm 0.07^{\mathrm{a}}$ & $0.47 \pm 0.05^{\mathrm{a}}$ & $0.51 \pm 0.07^{\mathrm{a}}$ \\
Gumminess (kg) & $2.44 \pm 0.30^{\mathrm{c}}$ & $1.29 \pm 0.16^{\mathrm{d}}$ & $3.77 \pm 0.40^{\mathrm{b}}$ & $3.52 \pm 0.28^{\mathrm{b}}$ & $4.35 \pm 0.66^{\mathrm{a}}$ \\
Springiness & $0.78 \pm 0.01^{\mathrm{d}}$ & $0.85 \pm 0.02^{\mathrm{c}}$ & $0.86 \pm 0.03^{\mathrm{bc}}$ & $0.88 \pm 0.03^{\mathrm{b}}$ & $0.90 \pm 0.02^{\mathrm{a}}$ \\
Chewiness (kg) & $1.89 \pm 0.22^{\mathrm{c}}$ & $1.04 \pm 0.14^{\mathrm{d}}$ & $3.19 \pm 0.33^{\mathrm{b}}$ & $3.28 \pm 0.28^{\mathrm{b}}$ & $4.24 \pm 0.74^{\mathrm{a}}$ \\
\hline
\end{tabular}

All values are mean $\pm \mathrm{SD}$.

${ }^{1)}$ Treatments: Control, $20 \%$ back fat; Control-L, replacement of $10 \%$ back fat with only water; T1, replacement of $10 \%$ back fat with DFG gel; T2, replacement of $12.5 \%$ back fat with DFG gel; T3, replacement of $15 \%$ back fat with DFG gel.

${ }^{\mathrm{a}-\mathrm{d}}$ Means in a row with different superscript letters are significantly different $(p<0.05)$.

Table 5. Sensory properties of low-fat frankfurters formulated with duck feet gelatin (DFG) gel

\begin{tabular}{|c|c|c|c|c|c|}
\hline \multirow{2}{*}{ Traits } & \multirow{2}{*}{ Control } & \multirow{2}{*}{ Control-L } & \multicolumn{3}{|c|}{ "Treatments ${ }^{1)}$} \\
\hline & & & T1 & $\mathrm{T} 2$ & T3 \\
\hline Color & $8.45 \pm 0.69$ & $7.73 \pm 0.47$ & $8.09 \pm 0.70$ & $8.00 \pm 0.45$ & $8.18 \pm 0.60$ \\
\hline Flavor & $8.27 \pm 0.65^{\mathrm{a}}$ & $7.27 \pm 0.65^{\mathrm{c}}$ & $7.45 \pm 0.69^{b c}$ & $7.64 \pm 0.50^{b c}$ & $7.91 \pm 0.54^{\mathrm{ab}}$ \\
\hline Tenderness & $8.09 \pm 0.54^{\mathrm{a}}$ & $7.36 \pm 0.67^{\mathrm{b}}$ & $7.64 \pm 0.92^{\mathrm{ab}}$ & $7.64 \pm 0.50^{\mathrm{ab}}$ & $8.00 \pm 0.89^{a b}$ \\
\hline Juiciness & $8.27 \pm 0.47^{\mathrm{a}}$ & $7.18 \pm 0.60^{b}$ & $7.73 \pm 0.47^{\mathrm{ab}}$ & $7.55 \pm 0.52^{\mathrm{ab}}$ & $8.00 \pm 0.45^{\mathrm{a}}$ \\
\hline Off-flavor & $8.36 \pm 0.50^{\mathrm{a}}$ & $7.73 \pm 0.90^{\mathrm{bc}}$ & $7.45 \pm 0.52^{\mathrm{c}}$ & $7.73 \pm 0.90^{\mathrm{bc}}$ & $8.09 \pm 0.30^{\mathrm{ab}}$ \\
\hline Overall acceptance & $8.18 \pm 0.60^{\mathrm{a}}$ & $7.27 \pm 0.47^{\mathrm{b}}$ & $7.45 \pm 0.93^{\mathrm{ab}}$ & $7.55 \pm 0.82^{\mathrm{ab}}$ & $7.82 \pm 0.75^{\mathrm{a}}$ \\
\hline
\end{tabular}

All values are mean \pm SD.

${ }^{1)}$ Treatments: Control, $20 \%$ back fat; Control-L, replacement of $10 \%$ back fat with only water; T1, replacement of $10 \%$ back fat with DFG gel; T2, replacement of $12.5 \%$ back fat with DFG gel; T3, replacement of $15 \%$ back fat with DFG gel.

${ }^{\mathrm{a}-\mathrm{c}}$ Means in a row with different superscript letters are significantly different $(p<0.05)$.

It would be possible to prevent lowering the cohesiveness of sausages by using DFG as a fat replacer. A similar trend in cohesiveness was reported by Crehan et al. (2000), and Pereira et al. (2011) suggesting that the reduced cohesiveness values were influenced by a decrease in protein content and increase in moisture content. Collagen fiber can provide texture and cohesion to a meat emulsion by retaining and swelling water chemically and contribute to the firmness of the sausage (Pereira et al., 2011), but no significant effect on cohesiveness was found as collagen fiber was increased in frankfurters. Similar to a former study, the DFG gel level in the frankfurters did not alter cohesiveness significantly ( $p>0.05)$.

Contrary to other texture parameters, the springiness of control-L was significantly higher than that of the control treatment. Crehan et al. (2000) also reported that reducing fat resulted in a significant increase in springiness of frankfurters. However, as the replacement ratio increased in low-fat frankfurters, springiness increased significantly and was higher than that of the control $(p<0.05)$. In previous studies, adding of collagen fiber had no effect on springiness of meat products (Huda et al. 2013; Hsu and Sun, 2006), but other studies reported that as pork connective tissue content increases, higher springiness was observed in reduced-fat bologna (Osburn et al., 1997).
Yang et al. (2007) reported that the viscoelasticity of gelatin and myosin mixtures are significantly higher than pure myosin, suggesting interaction between myosin and gelatin that might lead to higher elasticity. Thus, adding DFG gel affected the textural properties of low-fat frankfurters and greatly improved the softer texture of low-fat frankfurters.

\section{Sensory evaluation}

The sensory evaluation results of the low-fat frankfurters formulated with DFG gel is shown in Table 5. Among the treatments, the control had the highest score for all factors. Color had no significant differences $(p>0.05)$ based on the lack of a difference in redness among the treatments. In spite of significant differences in CIE $\mathrm{L}^{*}$ and $b^{*}$ of treatments, hedonic acceptability scale is strongly greatly associated with CIE $a^{*}$ value instrumental color evaluation in red meat (O'Sullivan et al., 2003). The tenderness of frankfurters replaced with DFG gel was not significantly different from that of the control $(p>0.05)$. Freitas et al. (2004) reported that hardness is an important textural attribute to determine acceptability of sausage. In this study, although increased hardness was observed as addition of DFG gel, tenderness was similar to that of the control. According to Meullenet et al. (1994), the increas- 
ing collagen fiber produced tough frankfurters and decreased juiciness, whereas adding water improves juiciness. For this reason, although cooking yield of low-fat frankfurter formulated with DFG gel was lower than that of the control $(p>0.05)$, the juiciness of low-fat frankfurters treated with DFG gel had no significant differences from the control. The flavor score for the T1 and T2 treatments was significantly lower than that of the control $(p<$ $0.05)$, but the $\mathrm{T} 3$ treatment has no significant differences from the control $(p>0.05)$. In contrast, panelists recognized significant off-flavor in the T1 treatment $(p<0.05)$. Sadler and Young (1993) also found a slight decrease in flavor as collagen content increases. In terms of unique flavor of collagen, Meullenet et al. (1994) suggested using collagen level under $2 \%$ to reduce the objectionable taste of final product. Thus, further studies will be needed to understand the effect of collagen and gelatin on off-flavor of meat products. Consequently, the low-fat frankfurter prepared with $5 \%$ back fat and $15 \%$ DFG gel showed similar was overall acceptance compared to than that of control $(p>0.05)$, and this result suggested that the replacement of back fat with DFG gel could improve the decline of flavor, tenderness, and juiciness satisfaction of low-fat frankfurters which resulted from reduction in added fat amount.

In conclusion, the replacement of back fat with DFG gel decreased the fat content of low-fat frankfurters which were ranged from $6.34 \%$ to $10.49 \%$. Adding DFG gel decreased lightness but increased yellowness of the lowfat frankfurters. However, no influence on redness of low-fat frankfurters was observed. In addition, DFG gel increased cooking yield of low-fat frankfurters, contributing to improved textural properties and sensory satisfaction. In terms of sensory properties, the low-fat frankfurter formulated with $5 \%$ back fat and $15 \%$ DFG gel showed similar satisfaction score for the flavor, tenderness, juiciness, and overall acceptance compared to the regular frankfurters ( $20 \%$ back fat). Therefore, DFG gel could be a useful source to reduce and/or replace animal fat in frankfurters, as a fat replacer.

\section{Acknowledgements}

This research was supported (111027-02-2-HD110) by the Rural Development Administration (Republic of Korea). The authors were supported by the Brain Korean 21 Plus (BK 21 Plus) Project from Ministry of Education and Human Resources Development.

\section{References}

1. AOAC (2000) Official methods of analysis of AOAC. Vol. 41. (17th ed.). Washington DC: Association of Official Analytical Chemists.

2. Bourne, M. C. (1978) Texture profile analysis. Food Technol. 32, 62-66.

3. Candogan, K. and Kolsarici, N. (2003) The effects of carrageenan and pectin on some quality characteristics of low-fat beef frankfurters. Meat Sci. 64, 199-206.

4. Carballo, J., Mota, N., Baretto, G., and Colmenero, F. J. (1995) Binding properties and colour of bologna sausage made with varying fat levels, protein levels and cooking temperatures. Meat Sci. 41, 301-313.

5. Choi, S. S. and Regenstein, J. M. (2000) Physicochemical and sensory characteristics of fish gelatin. J. Food Sci. 65, 194199.

6. Choi, Y. S., Choi, J. H., Han, D. J., Kim, H. Y., Kim, H. W., Lee, M. A., Chung, H. J., and Kim, C. J. (2012) Effects of laminaria japonica on the physico-chemical and sensory characteristics of reduced-fat pork patties. Meat Sci. 91, 1-7.

7. Choi, Y. S., Choi, J. H., Han, D. J., Kim, H. Y., Lee, M. A., Kim, H. W. Jeong, J. Y., and Kim, C. J. (2009) Characteristics of low-fat meat emulsion systems with pork fat replaced by vegetable oils and rice bran fiber. Meat Sci. 82, 266-271.

8. Cierach, M., Modzelewska-Kapitula, M., and Szacilo, K. (2009) The influence of carrageenan on the properties of low-fat frankfurters. Meat Sci. 82, 295-299.

9. Claus, J. R. and Hunt, M. C. (1991) Low-fat, high addedwater bologna formulated with texture-modifying ingredients. J. Food Sci. 56, 643-647.

10. Claus, J. R., Hunt, M. C., Kastner, C. L., and Kropf, D. H. (1990) Low-fat, high-added water bologna: effects of massaging, preblending, and time of addition of water and fat on physical and sensory characteristics. J. Food Sci. 55, 338-341.

11. Cliche, S., Amiot, J., Averzard, C., and Gariépy, C. (2003) Extraction and characterization of collagen with or without telopeptides from chicken skins. Poultry Sci. 82, 503-509.

12. Crehan, C. M., Hughes, E., Troy, D. J., and Buckley, D. J. (2000) Effects of fat level and maltodextrin on the functional properties of frankfurters formulated with 5, 12 and $30 \%$ fat. Meat Sci. 55, 463-469.

13. Freitas, M. Q., Silva, T. J. P., Mano, S. B., and Chaves, J. B. P. (2004) Medidas instrumentais de textura e cor, em mortadela produzida com carne mecanicamente separada de frango. Higiene Alimentar 18, 66-70.

14. Gómez-Guillén, M. C., Gilménez, B., López-Caballero, M. E., and Montero, M. P. (2011) Functional and bioactive properties of collagen and gelatin from alternative sources: a review. Food Hydrocolloid. 25, 1813-1827.

15. Gudmundsson, M. and Hafsteinsson, H. (1997) Gelatin from cod skins as affected by chemical treatments. J. Food Sci. 62, 37-47.

16. Hsu, S. Y. and Sun, L. Y. (2006) Comparisons on 10 nonmeat protein fat substitutes for low-fat Kung-wans. J. Food Eng. 74, 47-53. 
17. Huda, M., Seow, E. K., Normawati, M. N., Nik Aisyah, N. M., Fazilah, A., and Easa, A. M. (2013) Effect of duck feet collagen addition on physicochemical properties of surimi. Int. Food Res. J. 20, 537-544.

18. Keeton, J. T. (1994) Low-fat meats products technological problems with processing. Meat Sci. 36, 261-276.

19. Kim, C. J., Kim, K. H., Kim, M. J., and Kim, S. D. (2010) Extraction and bleaching of acid- and pepsin-soluble collagens from shark skin and muscle. Korean J. Food Preserv. 17, 9199.

20. Lin, Y. K. and Liu, D. C. (2006) Comparison of physicalchemical properties of type I collagen from different species. Food Chem. 99, 244-251.

21. Meullenet, J. F., Chang, H. C., Carpenter, J. A., and Resurreccion, A. V. A. (1994) Textural properties of chicken frankfurters with added collagen fibers. J. Food Sci. 59, 729-733.

22. Nagai, T. and Suzuki, N. (2000) Isolation of collagen from fish waste material - skin, bone and fins. Food Chem. 68, 277-281.

23. O’Sullivan, M. G., Byrne, D. V., Martens, H., Gidskehaug, G. H., Andersen, H. J., and Martens, M. (2003) Evaluation of pork colour: prediction of visual sensory quality of meat from instrumental and computer vision methods of colour analysis. Meat Sci. 65, 909-918.

24. Ockerman, H. W. and Hansen, C. L. (2000) Poultry by-products: Animal by-product processing \& utilization. 1st ed, CRC Press, Boca Raton, pp. 439-456.

25. Osburn, W. N. and Mandigo, R. W. (1998) Reduced-fat bologna manufactured with poultry skin connective tissue gel. Poultry Sci. 77, 1574-1584.
26. Osburn, W. N., Mandigo, R. W., and Calkins, C. R. (1999) Utilization of desinewed beef connective tissue gel in reduced-fat bologna. J. Muscle Food. 10, 29-50.

27. Osburn, W. N., Mandigo, R. W., and Eskridge, K. M. (1997) Pork skin connective tissue gel utilization in reduced-fat bologna. J. Food Sci. 62, 1176-1182.

28. Park, J. H. (2013) Functional characterization of gelatin extracted from duck feet and its utilization. Master thesis, Konkuk Univ., Seoul, South Korea.

29. Pereira, A. G. T., Ramos, E. M., Teixeira, J. T., Cardoso, G. P., Ramos, A. L. S., and Fontes, P. R. (2011) Effects of the addition of mechanically debonded poultry meat and collagen fiber on quality characteristics of frankfurter-type sausages. Meat Sci. 89, 519-525.

30. Pietrasik, Z. (1999) Effect of content of protein, fat and modified starch on binding textural characteristics, and colour of comminuted scalded sausages. Meat Sci. 51, 17-25.

31. Prabhu, G. A., Doerscher, D. R., and Hull, D. H. (2004) Utilization of pork collagen protein in emulsified and whole muscle meat products. J. Food Sci. 69, C388-C392.

32. Sadler, D. H. N. and Young, O. A. (1993) The effect of preheated tendon as a lean meat replacement on the properties of fine-emulsion sausages. Meat Sci. 35, 259-268.

33. SAS (2010) SAS/STAT Software for PC. Release 9.2, SAS Institute Inc., Cary, NC, US.

34. Yang, Y. L., Zhou, G. H., Xu, X. L., and Wang, Y. (2007) Rheological properties of myosin-gelatin mixtures. J. Food Sci. 72, C270-C275.

(Received 2013.12.6/Revised 2014.4.8/Accepted 2014.5.7) 